Article

\title{
Correlation of Fish Assemblages with Habitat and Environmental Variables in a Headwater Stream Section of Lijiang River, China
}

\author{
Jian Huang ${ }^{1,2}$, Liangliang Huang ${ }^{1,3, * \mathbb{C}}$, Zhiqiang $\mathrm{Wu}^{3}$, Yuanmin $\mathrm{Mo}^{1,3}$, Qi Zou ${ }^{1}$, \\ Naicheng $\mathrm{Wu}^{4,5}$ (i) and Zhongbing Chen 6 (1) \\ 1 College of Environmental Science and Engineering, Guilin University of Technology, Guilin 541004, China; \\ jianhuang1994@126.com (J.H.); yumimok@163.com (Y.M.); bruce2986@126.com (Q.Z.) \\ 2 Guangxi Key Laboratory of Environmental Pollution Control Theory and Technology, Guilin 541004, China \\ 3 Collaborative Innovation Center for Water Pollution Control and Water Safety in Karst Area, \\ Guilin University of Technology, Guilin 541004, China; wuzhiqiang@glut.edu.cn \\ 4 Institute of Advanced Studies, Aarhus University, Høegh-Guldbergs Gade 6B, 8000 Aarhus C, Denmark; \\ naichengwu88@gmail.com \\ 5 Department of Health and Environmental Sciences, Xi'an Jiaotong-Liverpool University, \\ Suzhou 215123, China \\ 6 Faculty of Environmental Sciences, Czech University of Life Sciences Prague, Kamýcká 129, \\ 16500 Prague, Czech Republic; chenz@fzp.czu.cz \\ * Correspondence: llhuang@glut.edu.cn; Tel.: +86-773-2536372
}

Received: 19 January 2019; Accepted: 17 February 2019; Published: 21 February 2019

check for updates

\begin{abstract}
In order to determine the relationship between stream habitat and fish assemblages, an investigation of fish assemblages and environmental variables in different habitat types was carried out in the headwater stream section of Lijiang River, China, from September to November 2016. In total, 2968 individuals belonging to 4 orders, 11 families, 26 genera and 37 species were collected. Cypriniformes emerged as the most species-rich order, accounting for $62.2 \%$ of the total species. The dominant species were Pseudogastromyzon fangi, Zacco platypus, Acrossocheilus parallens and Erromyzon sinensis. Non-metric multidimensional scaling (NMDS) and permutational multivariate analysis of variance (PERMANOVA) revealed that fish assemblages were not affected by habitat type. However, one-way ANOVA results showed that species richness, fish abundance, fish density and Shannon index were significantly affected by habitat type. Redundancy analysis (RDA) further revealed that altitude, velocity, conductivity, turbidity, depth and wetted width had significant relationships within fish assemblages, whereas water temperature, dissolved oxygen and substrate size were less important in this study, and different fish species preferred different environmental variables potentially due to differences in species' ecological requirements. Although habitat type did not affect overall fish assemblages, habitat heterogeneity played an important role in fish diversity. Hence, maintaining diverse stream habitats or restoring them are of key importance for fish diversity conservation and sustainability management of rivers.
\end{abstract}

Keywords: habitat; fish assemblages; environmental variables; headwater stream; Lijiang River

\section{Introduction}

In the broad sense, river habitat includes all the physical, chemical and biological characteristics in a river. In practical application, river habitat generally refers to the physical structure of rivers, including the river bed, bank and riparian zone, and it is a key component of stream ecosystems, playing a major role in determining biotic assemblages and stream integrity [1,2]. Since the 1980s, 
river ecologists have paid considerable attention to the study of river habitats, and biological factors have been widely used to assess the habitat quality of aquatic organisms [3,4]. Fish are particularly sensitive to changes in river habitats. They are therefore good response indicators as they integrate the effects of multiple stressors [5]; they persist and recover from natural disturbances and may also reflect both current and long-term environmental effects [6]. The relationship between fish assemblage and river habitat has been the subject of many studies worldwide, and it is evident that river habitat is an important determinant of the condition of fish assemblage in rivers $[7,8]$. Fish species diversity has been shown to increase as habitat diversity increases [9]. Habitat alterations that reduce complexity or decrease the stability of environmental conditions have been shown to reduce fish diversity and abundance $[10,11]$. Habitat type and connectivity are considered as the two most important factors in shaping divergent dispersal behavior in a desert-dwelling fish [12]. In addition, environmental variables such as current velocity, water depth, substrate size and $\mathrm{pH}$ have important effects on the growth and reproduction of the fish assemblages $[13,14]$.

Research on mountainous stream habitats has concentrated on developed countries, such as those in Europe and North America, in the past decades [15-18]. In China, the study of river habitat and its correlation with biological communities is only in its early stage, and only a limited number of studies on mountainous stream habitat are available. In recent years, classification and assessment of river habitat have been widely used in, for instance, Liao River Basin, Naoli River Watershed, and Dong River [19-21]. Some studies on river habitats and biological communities have focused on benthic animals, but there are only a few studies on the relationship between river habitat and fish assemblages [22,23]. It is well known that fish biodiversity in Chinese rivers has dramatically decreased [24-26]. It is therefore very important to reveal the relationship between fish assemblages and environmental variables and stream habitats, which can be beneficial for fish biodiversity conservation and river rehabilitation [27-29].

Different habitat types within a stream often harbor different fish assemblages, and the relationship between fish assemblage and environmental variables has been acknowledged [30,31]. However, which factors (substrate composition, stream width, current velocity, physico-chemical factors, altitude, etc.) contribute most to fish assemblage variations is not well studied [32]. Headwater streams differ widely in physical, chemical, and biotic attributes, thus providing habitats for a range of unique species, which contribute to the biodiversity of a river system [33]. Given the strong spatial variation of habitat types within rivers, we expected strong variations in fish assemblages (hypothesis $i$ ). Likewise, differences in species ecological requirements may lead to spatial variation in community structure and assemblages (hypothesis ii). Therefore, the main purposes of this study were: (1) to compare the differences in fish assemblages among different habitats; and (2) to highlight which environmental variables have the most influence on fish assemblages.

\section{Materials and Methods}

\subsection{Study Area}

Lijiang River is located in Guangxi, and it originates from Mao'er Mountain (altitude $2141.5 \mathrm{~m}$ ), the highest mountain in South China (Figure 1). The catchment area is $2173.29 \mathrm{~km}^{2}$ with a mean slope of $0.58 \%$. Dominant substrata consist of gravel and cobble with a mean particle size of 0.03-0.06 $\mathrm{m}$ [34]. Lijiang River flows southward with a length of $214 \mathrm{~km}$ and an average width of $305 \mathrm{~m}$. Lijiang River has typical rain source characteristics and the bankfull flow is $7810 \mathrm{~m}^{3} / \mathrm{s}$, usually occurring in May and June [35]. Strong seasonal variations in river flow affect hydrological characteristics and the aquatic ecosystem, especially in dry season, which occurs between October and March with a flow of 20\% average annual runoff [36]. The river has an extremely uneven flow during the year, mainly due to the huge heavy rainfall during the southeast monsoon in the upstream of the river flowing in a steep watershed. Overexploitation could be the largest threat to fish biodiversity in Lijiang River, and dam construction and sand extraction in the upstream sections could also contribute to the decrease of fish diversity $[35,37]$. 


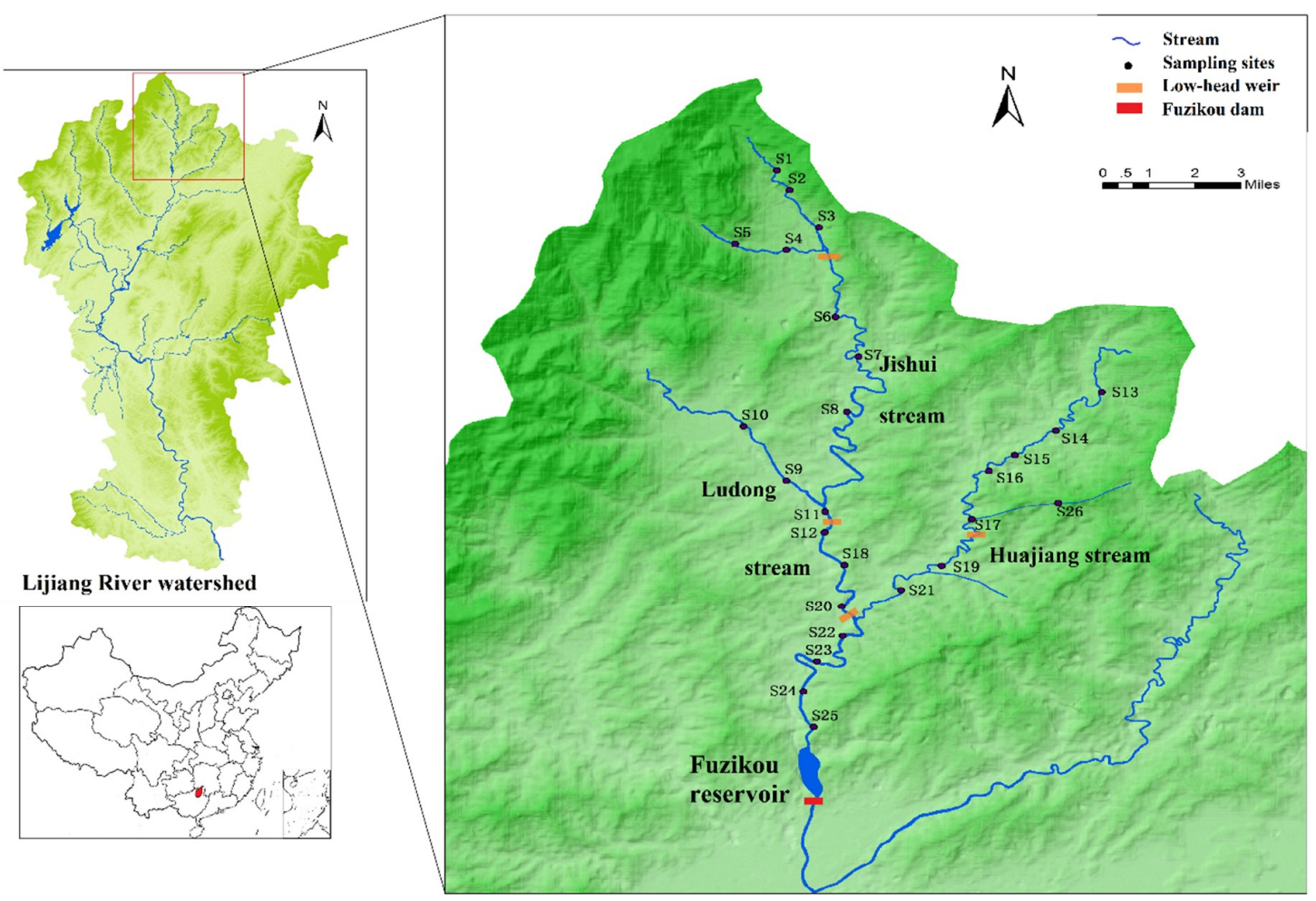

Figure 1. Study area location and sampling sites in upstream section of Lijiang River.

This study area is located in upstream section of Lijiang River, including Jishui stream, Ludong stream, and Huajiang stream (Figure 1). The average annual rainfall is up to $2600 \mathrm{~mm}$ and the average annual temperature is $16.5-20.2^{\circ} \mathrm{C}$. The substrate is dominated by pebbles [38]. All stream sections with an average width of $45 \mathrm{~m}$ are mountainous with a turbulent water-flow and a large hydraulic gradient $(31.7 \% 0)$. The vegetation on both sides of the stream is mixed, mostly consisting of coniferous forest, broad-leaved forest and bamboo forest [39]. The Fuzikou Reservoir was established in January 2018 in Ludong stream by means of a dam for the purpose of flood control, ecological hydration of Lijiang River, and power generation. The reservoir has a water storage capacity of $1.88 \times 10^{8} \mathrm{~m}^{3}$ with an impoundment level of $267 \mathrm{~m}$, which can compensate water to Lijiang River with a total of $1.11 \times 10^{8} \mathrm{~m}^{3}$ annually. Moreover, low head weirs are widely distributed in the tributaries, which allows local residents to use water for household and agriculture (Figure 1).

\subsection{Classification of Habitat Types}

According to the characteristics of the flow pattern, average velocity, slope and substrate component in the study area [40], the habitat was classified into three groups: lentic habitat (water depth $>40 \mathrm{~cm}$; velocity $<10 \mathrm{~cm} / \mathrm{s}$ ), slow flow-habitat (water depth $<30 \mathrm{~cm}$; velocity: $10-30 \mathrm{~cm} / \mathrm{s}$ ) and fast-flow habitat (water depth $<30 \mathrm{~cm}$; velocity $>40 \mathrm{~cm} / \mathrm{s}$ ). Each group was classified into several categories. Thus, the lentic habitat included pool and step pool, the slow-flow habitat included glide, run and secondary channel, and the fast-flow habitat included riffle and cascade. The slope, flow patterns and substrate composition of each habitat type are shown in Table 1.

\subsection{Field Sample Collection}

Fish samples were collected from 26 sampling sites (Figure 1) based on habitat representativeness and accessibility from September 10-20, October 10-20, and November 10-20, 2016. The average distance between two adjacent sampling sites was $2.34 \mathrm{~km}$. Fish were collected by a backpack electro-fisher (CWB-2000P, China; $12 \mathrm{~V}$ import, $250 \mathrm{~V}$ export), which was applied from downstream to upstream at each sampling site. Each sampling site was 150-200 m long with 3-5 different habitat 
types, and each sampling habitat type at a given site was sampled separately for about $30 \mathrm{~min}$. Prior to fish sampling, block nets (mesh size $=3 \mathrm{~mm}$ ) were installed at upstream and downstream ends of each site to avoid fish escaping and guarantee the capture of fish. Finally, a total of 102 samples were collected, including pool (22 samples), step pool (8 samples), glide (15 samples), run (6 samples), secondary channel (9 samples), riffle (28 samples), and cascade (14 samples). Collected fish with body length greater than $20 \mathrm{~mm}$ were identified in terms of species and then counted and returned to the stream. Fish with a body length of less than $20 \mathrm{~mm}$ were excluded [6]. The identification of fish species was mainly based on Freshwater fishes of Guangxi, China [41] and Fishes of Pearl River [42].

Table 1. River habitat types and their characteristics in upstream section of Lijiang River.

\begin{tabular}{|c|c|c|}
\hline Habita & Types & Feature \\
\hline \multirow{2}{*}{$\begin{array}{l}\text { Lentic } \\
\text { habitat }\end{array}$} & Pool & $\begin{array}{l}\text { Gentle slope, deep water }(>40 \mathrm{~cm}) \text {, smooth surface, very low velocity }(<10 \mathrm{~cm} / \mathrm{s}) \text {, often } \\
\text { connected with riffle and glide. The substrate consists of fine sand and cobble }(<15 \mathrm{~cm}) \text {. }\end{array}$ \\
\hline & Step pool & $\begin{array}{l}\text { Deep water }(>40 \mathrm{~cm}) \text {, very low velocity }(<10 \mathrm{~cm} / \mathrm{s}) \text {, located in the larger gradient of the } \\
\text { river, often form a step-pool pattern, water disorder with little spray splashing. The } \\
\text { substrate consists of fine sand and boulders }(>20 \mathrm{~cm}) \text { mostly. }\end{array}$ \\
\hline \multirow{3}{*}{$\begin{array}{l}\text { Slow-flow } \\
\text { habitat }\end{array}$} & Glide & $\begin{array}{l}\text { Low gradient, shallow water }(<30 \mathrm{~cm}) \text {, slow water flow }(10-30 \mathrm{~cm} / \mathrm{s}) \text {, smooth surface } \\
\text { with little turbulence. The substrate consists of cobble }(<15 \mathrm{~cm}) \text { mostly. }\end{array}$ \\
\hline & Run & $\begin{array}{l}\text { Slightly deep water }(20-40 \mathrm{~cm}) \text {, higher velocity than pool but still belongs to slow-flow } \\
(10-30 \mathrm{~cm} / \mathrm{s}) \text {, smooth surface without stirring. The substrate consists of fine sand and } \\
\text { cobble }(<15 \mathrm{~cm}) \text {. }\end{array}$ \\
\hline & $\begin{array}{l}\text { Secondary } \\
\text { channel }\end{array}$ & $\begin{array}{l}\text { Low gradient, slow flow }(10-30 \mathrm{~cm} / \mathrm{s}) \text {, located in the multiple channel sections and } \\
\text { isolated from main channel. The substrate consists of fine sand and cobble }(<15 \mathrm{~cm}) \text {. }\end{array}$ \\
\hline \multirow{2}{*}{$\begin{array}{l}\text { Fast-flow } \\
\text { habitat }\end{array}$} & Riffle & $\begin{array}{l}\text { High gradient, shallow water }(20-30 \mathrm{~cm}) \text {, high velocity }(30-60 \mathrm{~cm} / \mathrm{s}) \text {, water disorder } \\
\text { with white splashes. The substrate consists of fine sand and cobble }(<15 \mathrm{~cm}) \text {. }\end{array}$ \\
\hline & Cascade & $\begin{array}{l}\text { High gradient turbulence, shallow water }(20-30 \mathrm{~cm}) \text {, very fast flow }(>60 \mathrm{~cm} / \mathrm{s}) \text {, water } \\
\text { disorder with white spray splashing. The substrate consists of fine sand and cobble } \\
(<15 \mathrm{~cm}) \text { mostly. }\end{array}$ \\
\hline
\end{tabular}

Eight environmental variables were measured three times in each habitat (i.e., current velocity, water temperature, $\mathrm{pH}$, dissolved oxygen, conductivity, turbidity, wetted width, depth), and substrate size was obtained by measuring the median particle diameter of ten randomly chosen particles in each habitat type [43]. Current velocity was recorded in the middle of total depth using a printing flow velocity meter (LJD-10A, Runsun Instruments Inc., Chengdu, China). Water temperature, $\mathrm{pH}$, dissolved oxygen and conductivity were measured at the same place using a portable multi meter (HQ40d, Hach Company, Colorado, USA). Turbidity was measured applying a portable turbidity meter (2100Q, Hach Company, Colorado, USA). Wetted width of stream, maximum depth and substrate size were determined using a straightedge.

\subsection{Data Analyses}

Relative abundance (RA), RA = (Number of individuals for species A/Total number of individuals) $\times 100 \%$, was computed to determine the dominant species with a value more than $10 \%$ and rare fish with a value lower than $1 \%$ [44]. Shannon index was calculated as follows:

$$
\text { Shannon index }=-\sum_{i=1}^{\mathrm{S}} P_{i} \ln P_{i}, \quad\left(P_{i}=\frac{n_{i}}{\mathrm{~N}}\right)
$$

where $\mathrm{S}$ is the number of species; $\mathrm{N}$ is the total number of individuals within the community; $n_{i}$ is the number of individuals of the $i$-th species; and $P_{i}$ represents the proportion of the number of individuals of the $i$-th species relative to the total number of individuals in the sample [45].

To highlight differences in environmental variables (i.e., current velocity, depth, substrate size, wetted width, water temperature, $\mathrm{pH}$, dissolved oxygen, conductivity and turbidity) and fish 
community attributes (i.e., species richness, abundance, fish density and Shannon index) between different habitat types, we performed analysis of variance (ANOVA) using the function aov in $\mathrm{R}$ software (R Core Team, Vienna, Austria). Only if it was significant, a Tukey's HSD test could be performed to get the differences between any two different habitats using the function TukeyHSD in $\mathrm{R}$.

To visualize the differences in fish assemblage composition between habitat types, we performed non-metric multidimensional scaling (NMDS) using the function metaMDS in the R package vegan 2.5-3 (R Core Team, Vienna, Austria). Permutational analysis of variance (PERMANOVA) was used to make comparisons between fish assemblages in different habitat types. Before performing PERMANOVA, the multivariate homogeneity of group dispersions was tested by the function betadisper, which indicated that there was no difference in dispersion between groups ( $\mathrm{F}=0.49, p=0.82)$. The habitat type was used as explanatory variable for PERMANOVA, which was tested using the function adonis in the R package vegan $[46,47]$.

Redundancy analysis (RDA) was used as a direct gradient approach in order to determine how much variation in fish assemblages could be explained by environmental variables. Before ordination analysis, rare species were removed with occurrence frequency lower than $5 \%$ [48]. Then, fish abundance data with 21 species were Hellinger transformed using the function decosdtand in the $\mathrm{R}$ package vegan, in order to reduce the weight of abundant species while preserving Euclidean distances between samples in the multidimensional space [49]. A preliminary detrended correspondence analysis (DCA) performed on the transformed species data revealed a gradient length of 3.51 along the first axis, suggesting that redundancy analysis (RDA) was appropriate [50]. We performed RDA using the function $r d a$ and tested the significance using the function anova. In order to reduce the number of environmental variables entering the RDA, we used forward selection to get a parsimonious model. Forward selection was performed using the function ordiR2step with permutation test (999 permutations) in the R package vegan. The selected variables were then used as explanatory variables for RDA, and ANOVA was run with 9999 permutations to assess the significance of constraints using the function anova in the R package vegan. We ran the model (global test) for each constrained axis (setting: by = "axis") and each predictor (setting: by = "margins"). The predictors were log-transformed to meet the assumptions of normality and equal variance. All statistical analyses were run in R version 3.5.1 (R Core Team, Vienna, Austria) [51].

\section{Results}

\subsection{Environmental Variables of the Stream Habitats}

One-way ANOVA revealed that cascade had the highest average velocity $(96.38 \pm 34.15 \mathrm{~cm} / \mathrm{s})$, followed by riffle $(37.42 \pm 7.94 \mathrm{~cm} / \mathrm{s})$. The current velocities of cascade and riffle were significantly higher than other habitat types $(p<0.05)$. The average depths of pool and step pool were significantly higher than other habitat types $(p<0.05)$. Dissolved oxygen, $\mathrm{pH}$, turbidity and conductivity were not significantly different between habitat types. The substrate size in step pool was significantly larger than other habitat types except the run $(p<0.05)$ (Table 2$)$.

\subsection{Fish Assemblage Composition}

A total of 2968 fish were collected during this study, belonging to 4 orders, 11 families, 26 genera and 37 species (Table 3). Among these, Cypriniformes was the most species-rich order, accounting for $62.2 \%$ of the total species. The dominant species were Pseudogastromyzon fangi $(24.8 \%)$, Zacco platypus (21.0\%), Acrossocheilus parallens (12.8\%) and Erromyzon sinensis (10.5\%), which comprised $69.1 \%$ of the total fish abundance in our study. The dominant species varied in habitat type. For instance, Z. platypus, P. fangi and A. parallens were generalists, which were dominant species in most habitats. Moreover, Rhinogobius similis was a dominant species in glide and secondary channel, whereas E. sinensis and Rhinogobius leavelli were dominant species in riffle and cascade, respectively. 
Table 2. Results of one-way analysis of variance (ANOVA) with Tukey's HSD test for environmental variables (Mean \pm SD) among different habitat types in upstream section of Lijiang River.

\begin{tabular}{|c|c|c|c|c|c|c|c|}
\hline Habitat Types & Velocity $(\mathrm{cm} / \mathrm{s})$ & Substrate Size (cm) & Depth $(\mathrm{cm})$ & Conductivity $(\mu \mathrm{S} / \mathrm{cm})$ & Dissolved Oxygen (mg/L) & $\mathrm{pH}$ & Turbidity (NTU) \\
\hline Pool & $6.78 \pm 2.09^{\mathrm{a}}$ & $12.52 \pm 5.42^{\mathrm{a}}$ & $49.06 \pm 15.95^{a}$ & $64.37 \pm 48.57$ & $8.60 \pm 0.67$ & $7.88 \pm 0.89$ & $2.53 \pm 3.80$ \\
\hline Step pool & $8.35 \pm 1.24^{\mathrm{a}}$ & $23.54 \pm 8.69^{b}$ & $46.36 \pm 16.05^{\mathrm{a}}$ & $57.36 \pm 56.05$ & $8.19 \pm 0.27$ & $7.87 \pm 1.15$ & $0.82 \pm 0.52$ \\
\hline Glide & $20.52 \pm 7.50^{a}$ & $10.15 \pm 3.73^{a}$ & $24.28 \pm 9.26^{b}$ & $82.33 \pm 51.78$ & $8.76 \pm 0.46$ & $8.11 \pm 0.86$ & $2.94 \pm 4.51$ \\
\hline Run & $16.60 \pm 4.64^{\mathrm{a}}$ & $17.67 \pm 6.27^{b}$ & $28.65 \pm 10.31^{b}$ & $28.22 \pm 10.32$ & $8.28 \pm 0.42$ & $7.28 \pm 0.67$ & $1.30 \pm 1.35$ \\
\hline Secondary channel & $18.17 \pm 6.46^{\mathrm{a}}$ & $10.67 \pm 2.10^{a}$ & $33.12 \pm 12.91^{b}$ & $59.51 \pm 40.35$ & $7.75 \pm 1.55$ & $7.53 \pm 0.70$ & $1.33 \pm 0.86$ \\
\hline Riffle & $37.42 \pm 7.94^{b}$ & $11.67 \pm 4.59^{a}$ & $27.29 \pm 10.20^{b}$ & $56.40 \pm 38.38$ & $8.54 \pm 0.49$ & $7.78 \pm 0.78$ & $2.94 \pm 4.75$ \\
\hline Cascade & $96.38 \pm 34.15^{c}$ & $12.23 \pm 3.45^{\mathrm{a}}$ & $30.16 \pm 12.73^{b}$ & $54.29 \pm 28.81$ & $8.60 \pm 0.43$ & $7.76 \pm 0.47$ & $4.94 \pm 6.75$ \\
\hline
\end{tabular}

Notes: Different habitat types with different letters $(a, b, c)$ in the same column indicate significant differences.

Table 3. List of fish species and their distribution in different habitat types in upstream section of Lijiang River.

\begin{tabular}{|c|c|c|c|c|c|c|c|c|c|}
\hline \multirow{2}{*}{ Fish Species } & \multicolumn{7}{|c|}{ Fish Individuals in Different Habitat Types (N) } & \multirow{2}{*}{$\begin{array}{l}\text { Frequency of } \\
\text { Occurrence }\end{array}$} & \multirow{2}{*}{$\begin{array}{l}\text { Relative } \\
\text { Abundance }\end{array}$} \\
\hline & Pool & Step Pool & Glide & Run & Secondary Channel & Riffle & Cascade & & \\
\hline \multicolumn{10}{|l|}{ Cypriniformes } \\
\hline \multicolumn{10}{|l|}{ Balitoridae } \\
\hline Erromyzon sinensis (Chen, 1980$)$ & 29 & 4 & 21 & 2 & 5 & 195 & 56 & $49.0 \%$ & $10.51 \%$ \\
\hline Pseudogastromyzon fangi (Nichols, 1931) & 25 & 20 & 45 & 12 & 29 & 480 & 125 & $67.7 \%$ & $24.80 \%$ \\
\hline Vanmanenia lineata (Fang, 1935) & 1 & 1 & 1 & & & 14 & 9 & $12.8 \%$ & $0.88 \%$ \\
\hline $\begin{array}{l}\text { Vanmanenia pingchowensis (Fang, 1935) } \\
\text { Cobitidae }\end{array}$ & 1 & & & & 4 & 64 & 17 & $23.5 \%$ & $2.90 \%$ \\
\hline $\begin{array}{l}\text { Misgurnus anguillicaudatus (Cantor, 1842) } \\
\text { Cyprinidae }\end{array}$ & 2 & 1 & 25 & 4 & 3 & 1 & & $9.8 \%$ & $1.21 \%$ \\
\hline Acrossocheilus kreyenbergii (Regan, 1908) & 11 & & 2 & 2 & & 3 & 1 & $7.8 \%$ & $0.64 \%$ \\
\hline Acrossocheilus parallens (Nichols, 1931) & 208 & 24 & 40 & 34 & 36 & 27 & 12 & $69.6 \%$ & $12.84 \%$ \\
\hline Carassius auratus (Linnaeus, 1758) & & & & & & 1 & & $1.0 \%$ & $0.03 \%$ \\
\hline Cyprinus carpio (Linnaeus, 1758) & 2 & & & & 3 & & & $2.0 \%$ & $0.17 \%$ \\
\hline Microphysogobio chenhsienensis (Fang, 1938) & & & 20 & 2 & 2 & & 5 & $7.8 \%$ & $0.98 \%$ \\
\hline Microphysogobio kiatingensis $(\mathrm{Wu}, 1930)$ & & & 3 & & & & & $2.0 \%$ & $0.10 \%$ \\
\hline Onychostoma barbatulum (Pellegrin, 1908) & & & & & & & 1 & $1.0 \%$ & $0.03 \%$ \\
\hline Onychostoma gerlachi (Peters, 1881) & & & & & & 1 & & $1.0 \%$ & $0.03 \%$ \\
\hline Opsariichthys bidens (Günther, 1873) & 3 & & 13 & 4 & 6 & 57 & 5 & $18.6 \%$ & $2.97 \%$ \\
\hline Parasinilabeo assimilis (Wu and Yao, 1977) & 3 & & & & 1 & 12 & & $6.9 \%$ & $0.54 \%$ \\
\hline Pseudorasbora parva (Temminck and Schlegel, 1846) & 1 & 3 & & & 2 & 6 & & $5.9 \%$ & $0.40 \%$ \\
\hline Rhodeus ocellatus (Kner, 1866) & & & & & 1 & & & $1.0 \%$ & $0.03 \%$ \\
\hline
\end{tabular}


Table 3. Cont

\begin{tabular}{|c|c|c|c|c|c|c|c|c|c|}
\hline \multirow{2}{*}{ Fish Species } & \multicolumn{7}{|c|}{ Fish Individuals in Different Habitat Types (N) } & \multirow{2}{*}{$\begin{array}{l}\text { Frequency of } \\
\text { Occurrence }\end{array}$} & \multirow{2}{*}{$\begin{array}{c}\text { Relative } \\
\text { Abundance }\end{array}$} \\
\hline & Pool & Step Pool & Glide & Run & Secondary Channel & Riffle & Cascade & & \\
\hline Squalidus atromaculatus (Nichols and Pope, 1927) & 1 & 3 & 12 & 2 & 4 & 1 & 4 & $12.8 \%$ & $0.91 \%$ \\
\hline Zacco platypus (Temminck and Schlegel, 1846) & 31 & 12 & 49 & 5 & 54 & 369 & 103 & $55.9 \%$ & $21.00 \%$ \\
\hline Oreonectes platycephalus (Günther, 1868) & 1 & & & & & 1 & & $2.0 \%$ & $0.07 \%$ \\
\hline Schistura fasciolata (Nichols and Pope, 1927) & & & 1 & 1 & 3 & 14 & 3 & $13.7 \%$ & $0.74 \%$ \\
\hline Schistura incerta (Nichols, 1931) & & & & & 2 & 6 & 1 & $7.8 \%$ & $0.30 \%$ \\
\hline Traccatichthys pulcher (Nichols and Pope, 1927) & & & & & 1 & & & $1.0 \%$ & $0.03 \%$ \\
\hline \multicolumn{10}{|l|}{ Cichlidae } \\
\hline Oreochromis niloticus (Linnaeus, 1758) & & & & & 2 & & & $1.0 \%$ & $0.07 \%$ \\
\hline Gobiidae & & & & & & & & & \\
\hline Rhinogobius duospilus (Herre, 1935) & 11 & 3 & 18 & 3 & 9 & 47 & 19 & $49.0 \%$ & $3.71 \%$ \\
\hline Rhinogobius filamentosus (Wu, 1939) & 2 & & 1 & & & 1 & & $3.0 \%$ & $0.14 \%$ \\
\hline Rhinogobius similis (Gill, 1859) & 7 & & 45 & 3 & 28 & 25 & 35 & $31.4 \%$ & $4.82 \%$ \\
\hline Rhinogobius leavelli (Herre, 1935) & 10 & 3 & 26 & 3 & 10 & 77 & 54 & $48.0 \%$ & $6.17 \%$ \\
\hline Percichthyidae & & & & & & & & & \\
\hline Siniperca undulata (Fang and Chong, 1932) & & & 1 & & & & & $1.0 \%$ & $0.03 \%$ \\
\hline \multicolumn{10}{|l|}{ Siluriformes } \\
\hline \multicolumn{10}{|l|}{ Bagridae } \\
\hline Tachysurus albomarginatus (Rendahl, 1928) & 6 & 1 & 4 & 2 & 1 & 17 & 3 & $13.7 \%$ & $1.15 \%$ \\
\hline Tachysurus adiposalis (Oshima, 1919) & & & 1 & 1 & & 2 & 3 & $4.9 \%$ & $0.24 \%$ \\
\hline $\begin{array}{l}\text { Siluridae } \\
\text { S }\end{array}$ & & & & & & & & & \\
\hline Pterocryptis anomala (Herre, 1933) & 1 & & & & 1 & & & $2.0 \%$ & $0.07 \%$ \\
\hline Pterocryptis cochinchinensis (Valenciennes, 1840) & & & & & & 1 & & $1.0 \%$ & $0.03 \%$ \\
\hline Sisoridae & & & & & & & & & \\
\hline Glyptothorax fokiensis (Rendahl, 1925) & 2 & & 1 & & & 9 & 4 & $7.8 \%$ & $0.54 \%$ \\
\hline \multicolumn{10}{|l|}{ Synbranchiformes } \\
\hline \multicolumn{10}{|l|}{ Mastacembelidae } \\
\hline Macrognathus aculeatus (Bloch, 1786) & 1 & & 1 & & & & & $2.0 \%$ & $0.07 \%$ \\
\hline Abundance & 365 & 75 & 337 & 81 & 208 & 1442 & 460 & - & \\
\hline Species richness & 23 & 10 & 22 & 16 & 23 & 27 & 19 & - & \\
\hline
\end{tabular}




\subsection{Correlation between Fish Assemblage and Habitat Types}

Results of one-way ANOVA showed that the species richness in fast-flow habitat (riffle and cascade) was significantly higher than those in lentic habitats (pool and step pool) $(p<0.05)$. Fish abundance and fish density in fast-flow habitat (riffle and cascade) were significantly higher than those in other habitat types $(p<0.05)$. However, Shannon index was significantly lower in pools than in glides $(p<0.05)$ (Table 4$)$. Permutational analysis of variance and NMDS revealed fish assemblages were not significantly affected by habitat type (PERMANOVA, pseudo-F $=1.2, \mathrm{P}=0.292$ ) (Figure 2), which rejected hypothesis $i$.

Table 4. Results of one-way ANOVA of fish species richness, fish abundance, fish density and Shannon index (Mean \pm SD) among different habitat types in upstream section of Lijiang River.

\begin{tabular}{|c|c|c|c|c|}
\hline Habitat Types & Species Richness & Fish Abundance & Fish Density (ind $/ \mathrm{m}^{2}$ ) & Shannon Index $\left(H^{\prime}\right)$ \\
\hline Pool & $4.23 \pm 2.25^{\mathrm{a}}$ & $16.59 \pm 12.74^{a}$ & $0.34 \pm 0.27^{\mathrm{a}}$ & $0.93 \pm 0.59^{a}$ \\
\hline Step pool & $3.63 \pm 1.77^{\mathrm{a}}$ & $9.38 \pm 8.60^{\mathrm{a}}$ & $0.36 \pm 0.35^{\mathrm{a}}$ & $1.09 \pm 0.40^{\mathrm{a}, \mathrm{b}}$ \\
\hline Glide & $5.93 \pm 2.19^{a, b}$ & $22.47 \pm 11.97^{\mathrm{a}}$ & $0.31 \pm 0.14^{\mathrm{a}}$ & $1.47 \pm 0.37^{\mathrm{b}}$ \\
\hline Run & $5.00 \pm 3.35^{\mathrm{a}, \mathrm{b}}$ & $13.50 \pm 8.55^{\mathrm{a}}$ & $0.25 \pm 0.10^{\mathrm{a}}$ & $1.09 \pm 0.82^{\mathrm{a}, \mathrm{b}}$ \\
\hline Secondary channel & $5.67 \pm 3.20^{\mathrm{a}, \mathrm{b}}$ & $23.11 \pm 13.62^{a}$ & $0.47 \pm 0.28^{a}$ & $1.17 \pm 0.56^{\mathrm{a}, \mathrm{b}}$ \\
\hline Riffle & $6.89 \pm 2.42^{b}$ & $51.50 \pm 35.99^{b}$ & $1.15 \pm 0.93^{b}$ & $1.33 \pm 0.42^{a, b}$ \\
\hline Cascade & $6.07 \pm 2.70^{b}$ & $32.86 \pm 25.74^{b}$ & $0.73 \pm 0.44^{b}$ & $1.34 \pm 0.44^{\mathrm{a}, \mathrm{b}}$ \\
\hline
\end{tabular}

Notes: Different habitat types with different letters $(a, b)$ in the same column indicate significant differences.

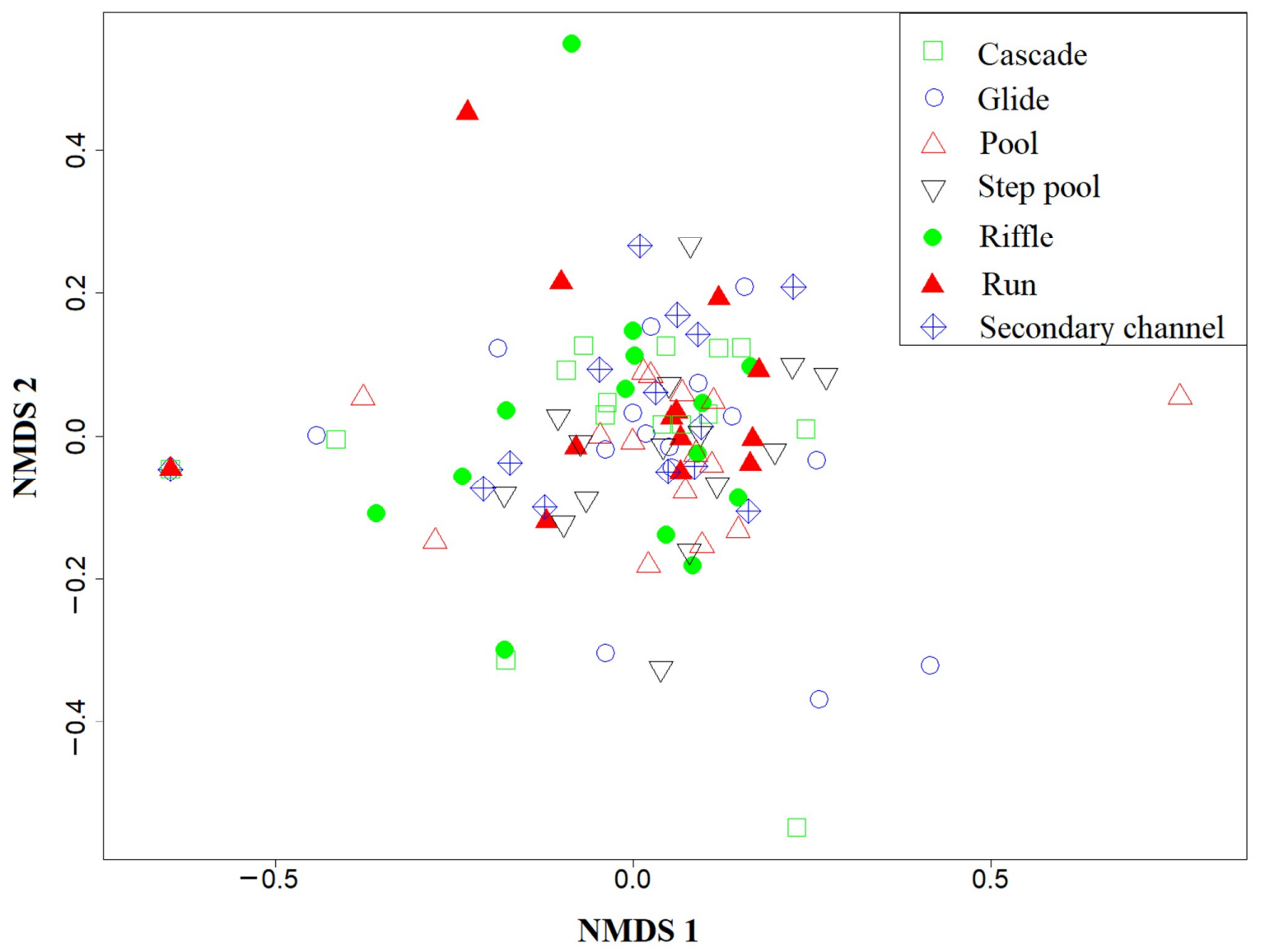

Figure 2. Non-metric Multidimensional Scaling (NMDS) ordination of fish assemblage in different habitat types in upstream section of Lijiang River. 


\subsection{Relationship between Fish Assemblage and Environmental Variables}

A total of 21 fish species were selected for redundancy analysis (RDA) with frequency of occurrence higher than 5\% (Table 3), and 6 environmental variables were selected after a forward stepwise selection including altitude, current velocity, conductivity, turbidity, depth and wetted width. The first two axes (RDA1 and RDA2) accounted for $57.49 \%$ and $31.24 \%$ of the variation of 21 fish species, respectively (Figure 3). Different fish species preferred different environmental variables, which supported hypothesis ii. For instance, P. fangi, E. sinensis, Ospariichthys bidens, Rhinogobius duospilus and Vanmanenia lineata were positively correlated with velocity but negatively related to depth. Acrossocheilus parallens was positively related to depth, but negatively related to velocity. Moreover, Z. platypus, $R$. similis, $R$. leavelli and Coreoperca whiteheadi also were positively correlated with conductivity, turbidity and wetted width, and negatively correlated to altitude.

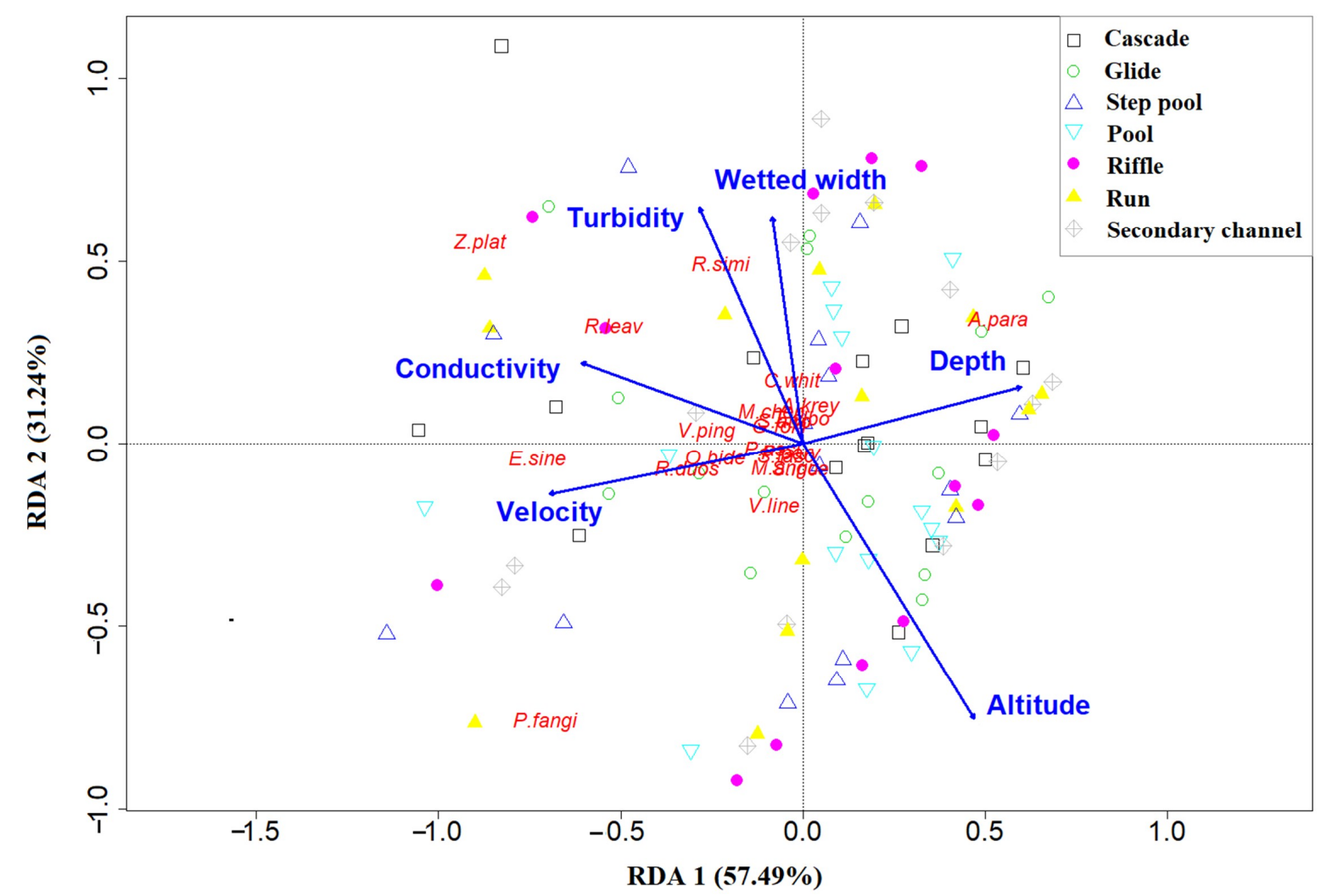

Figure 3. Redundancy analysis (RDA) ordination between fish assemblage and habitat types and environmental variables in upstream section of Lijiang River. (Notes: species names were used by generic acronym and the first four letters of the species name in Table 3.)

\section{Discussion}

The fish in the study area account for $40.7 \%$ of the total species richness in Lijiang River, contribute to fish diversity [37], thus suggesting that headwater streams play an important role in fish diversity in river networks $[25,33]$. Moreover, the rare species with a relative abundance value lower than $1 \%$ contribute a lot to fish diversity in this area, accounting for $70.3 \%$ of total species richness. A total of 10 fish species occurred only in one habitat type and 4 fish species only distributed in two stream habitats. For instance, Carassius autatus, Onychostoma gerlachi, Sinioerca scherzeri and Pterpcryptis cochinchinensis only distributed in riffle, and Rhodeus ocellatus, Traccatichthys pulcher and Oreochromis niloticus only occurred in the secondary channel, whereas Mircrophysogobio kiatingensis and Siniperca undulata only distributed in glide. One exotic species (O. niloticus) was recorded in this study area, whereas it was only previously recorded in downstream sections of Lijiang River [37]. It implied 
that the monitoring of $O$. niloticus should be considered due to its negative effect on native species [52], because its population will increase in coming years in the rivers of South China [53,54].

Different habitats are essential for fish assemblages in this study area. The total species richness in pool and step pool were found to play an important role in the breeding and growth for the fish community, and it is a refuge for fish assemblages in dry season, accounted for $63.9 \%$ of total native species $[55,56]$. The fast-flow habitat (i.e., riffle and cascade) with high velocity was the most prevalent in mountain stream, where the species richness and abundance accounted for $78.4 \%$ and $64.1 \%$, respectively. Many species preferred this type of habitat, such as Z. platypus and a variety of species of Gobiidae, Cobitidae and Balitoridae. Meanwhile, many fishes are well adapted to high-gradient, rapid flowing habitats and exhibit numerous morphological modifications in mouth, body shape and other associated structures and color patterns $[48,57]$. For instance, the pectoral fins of those fish in Balitoridae and Gobiidae evolve into a sucker-shaped form, allowing the fish to adhere to the substrate and thus avoid being washed away by rapid flow. Feeding patterns also have a certain impact on the habitat selection of fish [58]; thus, some small-size fish such as Microphysogobio chenhsienensis, Squalidus atromaculatus, and R. ocellatus prefer slow-flow habitat. For instance, secondary channels are usually separated by bars or stable island [59], which are good habitats for aquatic organisms [60,61]. Furthermore, more than $60 \%$ of fish species distributed in secondary channel, including 11 rare fish species, Cyprinus carpio, R. ocellatus, T. pulcher, Schistura incerta, Schistura fasciolata, Pseudorasbora parva, Mircrophysogobio chenhsienensis, S. atromaculatus, Parasinilabeo assimils, C. whiteheadi, and O. niloticus. Therefore, secondary channels are key elements for fish in the upstream sections of Lijiang River. Some studies revealed that individuals of the same species use different habitats depending on different stages of ontogeny [62,63]. However, we only studied from September to November in this study, which failed to uncover its function for larval and juvenile fish in breeding seasons. Thus, the utilization of different habitats for different fish species temporally, including larval and juvenile fish, should be further studied, which could be beneficial for fish diversity conservation in Lijiang River.

Habitat homogenization would lead to a decrease in species richness and fish diversity [64], and our study showed that fish richness and fish diversity were significantly affected by habitat type. Low-head weirs are widely distributed in upstream sections of Lijiang River, which might play a substantial role in reshaping habitats in terms of water depth, velocity, substratum composition and the transition between free-flowing water and interstitial zone, resulting in habitat homogenization on a small scale $[65,66]$. Moreover, the Fuzikou Reservoir in this study area started to be impounded in January 2018, with a storage capacity of $1.88 \times 10^{8} \mathrm{~m}^{3}$. By then, most of the sampling sites in our study would potentially be affected, which may reduce the fish species richness due to the increase of permanent lentic habitats and the decrease in hydrological connectivity. Dam or low-head weirs construction is the major threat to fish diversity in upstream sections in Lijiang River [33,37,67], whereas the effect of dam or weirs on fish assemblages mechanistically is poorly understood. Thus, these effects of low-head weirs or dams on fish assemblage in this area could be further studied in the near future.

\section{Conclusions}

The fish assemblages have insignificant differences among various habitat types in upstream section of Lijiang River, but fish richness and biodiversity are affected by habitat type. Altitude, velocity, wetted width, depth, turbidity and conductivity have also been shown to have a significant influence on the distribution of fish assemblages. For instance, different fish species preferred different environmental variables potentially due to differences in species ecological requirements. Although habitat type does not affect overall fish assemblages, habitat heterogeneity plays an important role in fish biodiversity. Hence, maintaining diverse stream habitats or restoring them are of key importance for fish diversity conservation and sustainability management of river.

Author Contributions: This paper received individual contributions from each author as specified: L.H. and J.H. developed the basic idea and designed the investigation. J.H., L.H., Y.M., Z.W., and Q.Z. performed the sampling 
collection and processing. J.H., Q.Z. and L.H. identified the fish samples. L.H., Y.M. and N.W. performed the data analyses. J.H. and L.H. led the original writing. L.H., Z.C. and N.W. reviewed and made corrections to improve the paper. All authors read the full paper and agreed to its publication.

Funding: National Natural Science Foundation of China: 51509042; Natural Science Foundation of Guangxi Zhuang Autonomous Region: 2016GXNSFAA380104, 2018GXNSFAA281022; 'Bagui Scholar' Construction Project: 2016A10; Guangxi Science and Technology Planning Project: GuiKe-AD18126018.

Acknowledgments: Thanks to $\mathrm{Li} \mathrm{Xu}$, Xiong Zheng and Qian Wang for field assistance, and Erik Jeppesen for English language improvement, and Eti Ester Levi for the code for data analysis. This study was funded by National Natural Science Foundation of China (51509042), Guangxi Natural Science Foundation (2016GXNSFAA380104,2018GXNSFAA281022) and Guangxi 'Bagui Scholar' Construction Project (2016A10) and Guangxi Science and Technology Planning Project (GuiKe-AD18126018). The constructive comments of four anonymous reviewers greatly improved our manuscript.

Conflicts of Interest: The authors declare no conflict of interest.

\section{References}

1. Newson, M.D.; Newson, C.L. Geomorphology, ecology and river channel habitat: Mesoscale approaches to basin-scale challenges. Prog. Phys. Geogr. 2000, 24, 195-217. [CrossRef]

2. Zeni, J.O.; Casatti, L. The influence of habitat homogenization on the trophic structure of fish fauna in tropical streams. Hydrobiologia 2014, 726, 259-270. [CrossRef]

3. Karr, J.R.; Dudley, D.R. Ecological perspectives on water quality goals. Environ. Manag. 1981, 5, 55-68. [CrossRef]

4. Van Liefferinge, C.; Simoens, I.; Vogt, C.; Cox, T.J.S.; Breine, J.; Ercken, D.; Goethals, P.; Belpaire, C.; Meire, P. Impact of habitat diversity on the sampling effort required for the assessment of river fish communities and IBI. Hydrobiologia 2010, 644, 169-183. [CrossRef]

5. Karr, J.R.; Fausch, K.D.; Angermeier, P.L.; Yant, P.R.; Schlosser, I.J. Assessing Biological Integrity in Running Waters: A Method and Its Rationale; Illinois Natural History Survey: Champaigne, IL, USA, Special Publication 5; 1986; p. 26.

6. Barbour, M.T.; Gerritsen, J.; Snyder, B.D.; Stribling, J.B. Rapid Bioassessment Protocols for Use in Streams and Wadable Rivers: Periphyton, Benthic Invertebrates and Fish, 2rd ed.; EPA 841-B-99-002; U.S. Environmental Protection Agency, Office of Water: Washington, DC, USA, 1999. Available online: https:/ / www.krisweb. com/biblio/gen_usepa_barbouretal_1999_rba.pdf (accessed on 20 December 2018).

7. Wang, L.; Seelbach, P.W.; Hughes, R.M. Introduction to landscape influences on stream habitats and biological assemblages. Am. Fish. Soc. Symp. 2006, 48, 1-23.

8. Fialho, A.P.; Oliveira, L.G.; Tejerina-Garro, F.L.; de Mérona, B. Fish-habitat relationship in a tropical river under anthropogenic influences. Hydrobiologia 2008, 598, 315-324. [CrossRef]

9. Gorman, O.T.; Karr, J.R. Habitat Structure and Stream Fish Communities. Ecology 1978, 59, 507-515. [CrossRef]

10. Lau, J.K.; Lauer, T.E.; Weinman, M.L. Impacts of channelization on stream habitats and associated fish assemblages in East Central Indiana. Am. Midl. Nat. 2006, 156, 319-330. [CrossRef]

11. Diana, M.; Allan, J.D.; Infante, D. The influence of physical habitat and land use on stream fish assemblages in southeastern Michigan. Am. Fish. Soc. Symp. 2006, 48, 359-374.

12. Mossop, K.D.; Moran, N.P.; Chapple, D.G.; Wong, B.B.M. Connectivity and habitat type shape divergent dispersal behavior in a desert-dwelling fish. Landsc. Ecol. 2017, 32, 1065-1078. [CrossRef]

13. Yu, S.L.; Lee, T.W. Habitat preference of the stream fish, Sinogastromyzon pulinensis (Homalopteridae). Zool. Stud. 2002, 41, 183-187.

14. Blanck, A.; Tedesco, P.A.; Lamouroux, N. Relationships between life-history strategies of European freshwater fish species and their habitat preferences. Freshw. Biol. 2007, 52, 843-859. [CrossRef]

15. Jones, N.E.; Tonn, W.M.; Scrimgeour, G.J.; Katopodis, C. Productive capacity of an artificial stream in the Canadian Arctic: Assessing the effectiveness of fish habitat compensation. Can. J. Fish Aquat. Sci. 2003, 60, 849-863. [CrossRef]

16. Mohseni, O.; Stefan, H.G.; Eaton, J.G. Global warming and potential changes in fish habitat in US streams. Clim. Chang. 2003, 59, 389-409. [CrossRef] 
17. Raven, P.J.; Holmes, N.T.H.; Vaughan, I.P.; Dawson, F.H.; Scarlett, P. Benchmarking habitat quality: Observations using River Habitat Survey on near-natural streams and rivers in northern and western Europe. Aquat. Conserv. -Mar. Freshw. Ecosyst. 2010, 20, S13-S30. [CrossRef]

18. Wood, J.L.A.; Belmar-Lucero, S.; Hutchings, J.A.; Fraser, D.J. Relationship of habitat variability to population size in a stream fish. Ecol. Appl. 2014, 24, 1085-1100. [CrossRef]

19. Zheng, B.H.; Zhang, Y.; Li, Y.B. Study of indicators and methods for river habitat assessment of Liao River Basin. Acta Sci. Circumstantiae 2007, 27, 928-936. (In Chinese)

20. Wang, J.H.; Tian, J.H.; Lv, X.G. Assessment of stream habitat quality in Naoli River Watershed, China. Acta Ecol. Sin. 2010, 30, 481-486. (In Chinese)

21. Wang, Q.; Yuan, X.Z.; Liu, H.; Zhang, Y.W. Rapid assessment model for mountain stream habitat and its application. J. Hydraul. Eng. 2011, 42, 928-933. (In Chinese)

22. Chu, L.; Wang, W.J.; Zhu, R.; Yan, Y.Z.; Chen, Y.F.; Wang, L.Z. Variation in fish assemblages across impoundments of low-head dams in headwater streams of the Qingyi River, China: Effects of abiotic factors and native invaders. Environ. Biol. Fishes 2015, 98, 101-112. [CrossRef]

23. Li, Y.R.; Tao, J.; Chu, L.; Yan, Y.Z. Effects of anthropogenic disturbances on alpha and beta diversity of fish assemblages and their longitudinal patterns in subtropical streams, China. Ecol. Freshw. Fish 2018, 27, 433-441. [CrossRef]

24. Fu, C.Z.; Wu, J.H.; Chen, J.K.; Qu, Q.H.; Lei, G.C. Freshwater fish biodiversity in the Yangtze River basin of China: Patterns, threats and conservation. Biodivers. Conserv. 2003, 12, 1649-1685. [CrossRef]

25. Li, J.H.; Huang, L.L.; Sato, T.; Zou, L.M.; Jiang, K.; Yahara, T.; Kano, Y. Distribution pattern, threats and conservation of fish biodiversity in the East Tiaoxi, China. Environ. Biol. Fishes 2013, 96, 519-533. [CrossRef]

26. Kang, B.; Huang, X.X.; Yan, Y.Z.; Yan, Y.R.; Lin, H.D. Continental-scale analysis of taxonomic and functional fish diversity in the Yangtze river. Glob. Ecol. Conserv. 2018, 15, e00442. [CrossRef]

27. Raat, A.J.P. Ecological rehabilitation of the Dutch part of the River Rhine with special attention to the fish. River Res. Appl. 2001, 17, 131-144. [CrossRef]

28. Dudgeon, D. River rehabilitation for conservation of fish biodiversity in monsoonal Asia. Ecol. Soc. 2005, 10, 15. [CrossRef]

29. Pokharel, K.K.; Basnet, K.B.; Majupuria, T.C.; Baniya, C.B. Correlations between fish assemblage structure and environmental variables of the Seti Gandaki River Basin, Nepal. J. Freshw. Ecol. 2018, 33, 31-43. [CrossRef]

30. Taylor, C.M. A large-scale comparative analysis of riffle and pool fish communities in an upland stream system. Environ. Biol. Fishes 2000, 58, 89-95. [CrossRef]

31. Magalhães, M.F.; Batalha, D.C.; Collares-Pereira, M.J. Gradients in stream fish assemblages across a Mediterranean landscape: Contributions of environmental factors and spatial structure. Freshw. Biol. 2002, 47, 1015-1031. [CrossRef]

32. Kautza, A.; Sullivan, S.M.P. Relative effects of local- and landscape-scale environmental factors on stream fish assemblages: Evidence from Idaho and Ohio, USA. Fundam. Appl. Limnol. 2012, 180, 259-270. [CrossRef]

33. Meyer, J.L.; Strayer, D.L.; Wakkace, J.B.; Eggert, S.L.; Helfman, G.S.; Leonard, N.E. The contribution of headwater streams to biodiversity in river networks. J. Am. Water Resour. Assoc. 2007, 43, 86-103. [CrossRef]

34. Yang, Y. Discussion on ecological and environmental water supplement target flow of Lijiang River. Guangxi Water Resour. Hydropower Eng. 2012, 3, 7-10. (In Chinese)

35. Li, R.; Chen, Q.; Tonina, D.; Cai, D. Effects of upstream reservoir regulation on the hydrological regime and fish habitats of the Lijiang River, China. Ecol. Eng. 2015, 76, 75-83. [CrossRef]

36. Li, R.; Chen, Q.; Ye, F. Modelling the impacts of reservoir operations on the downstream riparian vegetation and fish habitats in the Lijiang River. J. Hydroinformatics 2011, 13, 229-244. [CrossRef]

37. Ding, Y.; Wu, Z.Q.; Zhu, Z.J.; Yan, J. Species composition, trend biodiversity variation and conservation of the fish in Lijiang River (in China). Environ. Biol. Fishes 2018, 101, 675-685. [CrossRef]

38. Liang, R.F.; Liu, C. Investigation and research on water environment background value of Lijiang River. Guangxi Water Resour. Hydropower Eng. 1984, 2, 44-52. (In Chinese)

39. Guo, C.Q.; Fang, R.J.; Dai, J.F. Evolution and Prediction of Water Resources and Water Environment in the Upper Reaches of Lijiang River Basin; China Water Power Press: Beijing, China, 2011; p. 351. ISBN 9787508491172. (In Chinese) 
40. Han, Y.Q. Studies on fish species diversity and evolution trend in Lijiang River. J. Hydroecology 2010, 3, 132-135. (In Chinese)

41. Anonymous. Freshwater fishes of Guangxi, China, 2rd ed.; Guangxi People's Publishing House: Nanning, China, 2006; p. 535. ISBN 9787219057674. (In Chinese)

42. Zheng, C.Y. Fishes of Pearl River; Science Press: Beijing, China, 1989; p. 438. ISBN 9787030008657. (In Chinese)

43. Harrelson, C.C.; Rawlins, C.L.; Potyondy, J.P. Stream Channel Reference Sites: An Illustrated Guide to Field Technique; Gen. Tech. Rep. RM-245; U.S. Department of Agriculture, Forest Service, Rocky Mountain Forest and Range Experiment Station: Fort Collins, CO, USA, 1994; p. 61. Available online: https:/ /www.fs.fed.us / $\mathrm{rm} /$ pubs_rm/rm_gtr245.pdf (accessed on 20 December 2018).

44. Walag, A.M.P.; Canencia, M.O.P. Physico-chemical parameters and macrobenthic invertebrates of the intertidal zone of Gusa, Cagayan de Oro city, Philippines. Adv. Enivronmental Sci. Int. J. Bioflux Soc. 2016, 8, 71-82.

45. Magurran, A.E. Measuring Biological Diversity; Blackwell Publishing: Hoboken, NJ, USA, 2003; p. 264, ISBN 9780632056330.

46. Anderson, M.J. A new method for non-parametric multivariate analysis of variance. Austral. Ecol. 2011, 26, $32-46$.

47. Imai, N.; Seino, T.; Aiba, S.; Takyu, M.; Titin, J.; Kitayama, K. Effects of selective logging on tree species diversity and composition of Bornean tropical rain forests at different spatial scales. Plant Ecol. 2012, 213, 1413-1424. [CrossRef]

48. Li, J.H.; Huang, L.L.; Zou, L.M.; Kano, Y.; Sato, T.; Yahara, T. Spatial and temporal variation of fish assemblages and their associations to habitat variables in a mountain stream of north Tiaoxi River, China. Environ. Biol. Fishes 2012, 93, 403-417. [CrossRef]

49. Legendre, P.; Gallagher, E.D. Ecologically meaningful transformations for ordination of species data. Oecologia 2001, 129, 271-280. [CrossRef] [PubMed]

50. Lepš, J.; Šmilauer, P. Multivariate Analysis of Ecological Data Using CANOCO; Cambridge University Press: Cambride, UK, 2003; p. 110. ISBN 9780511076619.

51. R Core Team. R: A Language and Environment for Statistical Computing; R Foundation for Statistical Computing: Vienna, Austria, 2018; Available online: https:/ / www.r-project.org/ (accessed on 2 July 2018).

52. Gu, D.E.; Ma, G.M.; Zhu, Y.J.; Xu, M.; Luo, D.; Li, Y.Y.; Wei, H.; Mu, X.D.; Luo, J.R.; Hu, Y.C. The impacts of invasive Nile tilapia (Oreochromis niloticus) on the fisheries in the main rivers of Guangdong Province, China. Biochem. Syst. Ecol. 2015, 59, 1-7. [CrossRef]

53. Gu, D.E.; Yu, F.D.; Xu, M.; Wei, H.; Mu, X.D.; Luo, D.; Yang, Y.X.; Pan, Z.; Hu, Y.C. Temperature effects on the distribution of two invasive tilapia species (Tilapia zillii and Oreochromis niloticus) in the rivers of South China. J. Freshw. Ecol. 2018, 33, 521-534. [CrossRef]

54. Shuai, F.M.; Li, X.H.; Li, Y.F.; Jie, L.; Yang, J.P.; Lek, S. Forecasting the invasive potential of Nile tilapia (Oreochromis niloticus) in a large subtropical river using a univariate approach. Fundam. Appl. Limnol. 2015, 187, 165-176. [CrossRef]

55. Favrot, S.D.; Jonasson, B.C.; Peterson, J.T. Fall and winter microhabitat use and suitability for spring chinook Salmon parr in a US Pacific Northwest River. Trans. Am. Fish. Soc. 2018, 147, 151-171. [CrossRef]

56. Espírito-Santo, H.M.V.; Zuanon, J. Temporary pools provide stability to fish assemblages in Amazon headwater streams. Ecol. Freshw. Fish 2017, 2, 475-483. [CrossRef]

57. Neely, D.A.; Conway, K.W.; Mayden, R.L. Erromyzon yangi, a new hillstream loach (Teleostei: Balitoridae) from the Pearl River drainage of Guangxi Province, China. Ichthyol. Explor. Freshw. 2007, 18, 97-102.

58. Stergiou, K.I.; Karpouzi, V.S. Feeding habits and trophic levels of Mediterranean fish. Rev. Fish Biol. Fish. 2002, 11, 217-254. [CrossRef]

59. Jähnig, S.C.; Lorenz, A.; Hering, D. Hydromorphological parameters indicating differences between single- and multiple-channel mountain rivers in Germany, in relation to their modification and recovery. Aquat. Conserv. Mar. Freshw. Ecosyst. 2008, 18, 1200-1216.

60. Helfield, J.M.; Engström, J.; Michel, J.T.; Nilsson, C.; Jansson, R. Effects of River Restoration on Riparian Biodiversity in Secondary Channels of the Pite River, Sweden. Environ. Manag. 2012, 49, 130-141. [CrossRef] [PubMed]

61. Chiu, H.P.; Suen, J.P. The importance of providing multiple-channel sections in dredging activities to improve fish habitat environments. Water 2016, 8, 36. [CrossRef] 
62. Pennock, C.A.; Cathcart, C.N.; Hedden, S.C.; Weber, R.E.; Gido, K. Fine-scale movement and habitat use of a prairie stream fish assemblage. Oecologia 2018, 186, 831-842. [CrossRef] [PubMed]

63. Garcia, C.; Schumann, D.A.; Howell, J.; Graeb, B.D.S.; Bertrand, K.N.; Klumb, R.A. Seasonality, floods and droughts structure larval fish assemblages in prairie rivers. Ecol. Freshw. Fish 2018, 27, 389-397. [CrossRef]

64. Walrath, J.D.; Dauwalter, D.C.; Reinke, D. Influence of stream condition on habitat diversity and fish assemblages in an impaired upper Snake River Basin Watershed. Trans. Am. Fish. Soc. 2016, 145, 821-834. [CrossRef]

65. Mueller, M.; Pander, J.; Geist, J. The effects of weirs on structural stream habitat and biological communuities. J. Appl. Ecol. 2011, 48, 1450-1460. [CrossRef]

66. Smith, S.C.F.; Meiners, S.J.; Hastings, R.P.; Thomas, T.; Colombo, R.E. Low-head dam impacts on habitat and the functional composition of fish commuities. River Res. Appl. 2017, 33, 680-689. [CrossRef]

67. Zhu, Z.J.; Wu, Z.Q.; Huang, L.L.; Feng, W.L.; Ding, Y. Species composition and diversity of fish in the upper reach of Lijiang River. Sichuan J. Zool. 2015, 34, 126-132. (In Chinese)

(C) 2019 by the authors. Licensee MDPI, Basel, Switzerland. This article is an open access article distributed under the terms and conditions of the Creative Commons Attribution (CC BY) license (http:/ / creativecommons.org/licenses/by/4.0/). 